\title{
利用者ニーズに対応した到着時刻予測に基づくバス情報システムの実用的開発* \\ Practical development of a bus information system \\ based on the time-of-arrival prediction corresponding to user needs *
}

\author{
坂本邦宏 $* *$-久保田尚 $* * *$ ・ 中村要 $* * * *$ ・菅野光司 $* * * * *$ 谷島賢 \\ By Kunihiro SAKAMOTO** • Hisashi KUBOTA*** $\cdot$ Kaname NAKAMURA**** $\cdot$ Koji KANNO***** $\cdot$ Ken YAJIMA******
}

1. はじめに

かつては国内輸送機関の要であったバス交通は、 定時・低速走行の欠如、利用者の減少、バス事業者 の経営・サービスの悪化という悪循環に陥っている。 バス交通は、本来地域社会における不特定多数に与 えられたモビリティとして確保されるべきもので、 都市・地方のいずれにおいても重要な役割を担って いる。したがって、今後さらに高齢化が進むと予測 されるわが国にとっては、上記の課題は早急に解決 しなければならない問題である。現在各地で検討さ れている対策としては、運行本数増加やバス優先レ ーンの設置といったハード的な手法、バス優先信号 (PTPS)などのソフト的な手法、さらに、デマンドバ ス、コミュニティバス、バスロケーションシステム など利用者の多様なニーズに対応する施策などがあ る。特に、情報通信技術を用いた「バス情報提供シ ステム」はすでに全国各地で実験や実用化がなされ ており成果を上げつつある。しかし、先端技術を用 いているが故に年配者の使用性に問題のあるもの、 維持費用の問題から実験段階で終わってしまったも のなどの例も少なくない。

このような背景において、平成 12 年 11 月に埼 玉県川越市にて「誰もが使用可能な操作性を持った バス情報の提供」を理念とした「リクエスト方式の 自動通知型バス情報提供システム」の交通社会実験 が行われた ${ }^{1)}$ 。本研究では、その実験結果を受け、 実験時に浮き彫りとなった問題を改善し、さらに既

*キーワーズ : バス情報システム、到着時刻予測、GPS

** 正員、工博、埼玉大学工学部建設工学科

テ338-8570 埼玉県さいたま市下大久保 255

TEL 048-858-3549, FAX 048-855-7833

***正員、工博、埼玉大学大学院理工学研究科

*****学生会員、埼玉大学工学部建設工学科

******正員、埼玉県

******イーグルバス株式会社
存のバスロケーションシステムから、その長所・短 所等を検討することにより、実用システムとしての 使用性、信頼性、安定性を持ち合わせた「バス情報 提供システム」を構筑することを目的とした。また、 本研究で構筑したシステムの主要機能である「バス 到着時刻予測」の予測精度向上のための手法を見出 すことを目的とし研究・開発を行った。

\section{2. 新しいバス情報システムの提案と実用化の課題}

\section{（1）既存バス情報システム}

各地で導入が進んでいる様々なバス情報システム は、(1)固定端末型として、バス停や駅に設置される 電光掲示板などの不特定多数を対象とした固定端末

（情報キオスク等）のものや、パソコンや FAX な ど利用者が特定される固定端末のもの、といったも のある。また、(2)移動端末型としては、携帯電話や PDA などによってどこでも自由に情報を取得でき るもの、に大別される。移動端末型の主なバス情報 システムに関して、利用可能なインターフェイスと コンテンツについて表 1にまとめた。

表 1 既存の携帯端末型バスロケーションシステム

\begin{tabular}{|c|c|c|c|c|c|}
\hline & \multirow{2}{*}{ イターフェイス } & \multicolumn{4}{|c|}{ コテデッ } \\
\hline & & 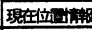 & 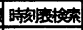 & 路線图 & 到活予測 \\
\hline \multirow{2}{*}{ ポケロク(京都) 2) } & 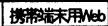 & 0 & 0 & & \\
\hline & Ex一儿(壾雅中) & & & & $\mathrm{O}$ \\
\hline \multirow{2}{*}{ 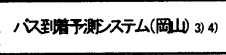 } & 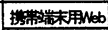 & & 0 & & 0 \\
\hline & イターネイ & 0 & 0 & 0 & 0 \\
\hline \multirow{2}{*}{ 八刀口浜松) 5) 6) } & 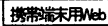 & 0 & & & \\
\hline & イターネ゙ & 0 & 0 & 0 & \\
\hline \multirow{2}{*}{ 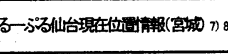 } & 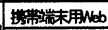 & 0 & 0 & & 0 \\
\hline & イターネ゙ト & 0 & 0 & $\mathrm{O}$ & 0 \\
\hline \multirow{3}{*}{ ハスく る(金沢) 9) } & 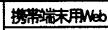 & 0 & 0 & & 0 \\
\hline & イターネ゙ト & 0 & 0 & 0 & 0 \\
\hline & Exール & & & & 0 \\
\hline \multirow{2}{*}{ 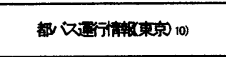 } & 撒违端束用Neb & 0 & 0 & & 0 \\
\hline & イターネ小 & 0 & 0 & & 0 \\
\hline \multirow{4}{*}{ 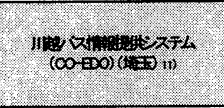 } & 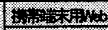 & 0 & 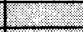 & 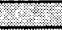 & 0 \\
\hline & tes-ist & 0 & 0 & 0 & 0 \\
\hline & $E x-\mu$ & 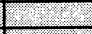 & 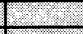 & 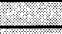 & 0 \\
\hline & OH: & 0 & 0 & -2 & 0 \\
\hline
\end{tabular}

利用可能なインターフェイスのほとんどは携帯端末 のWEB 機能（i モード等）を利用したものであり、 
既存のバス情報システムの課題点として、次の 2 点 が指摘できる。

(1)利用者は情報を能動的に取得する必要があること。

(2)バス交通の重要なターゲットである高齢者を含む IT 弱者にとって利用しやすいシステムに必ずし もなっていないこと。

\section{(2) 社会実験結果からの課題と解決案}

前述の課題点を加味し、平成 12 年に川越市で実 施された P\&BR 社会実験の一環として、バス情報 提供実験が害施された。その際提案された事項は、

(1)リクエスト型接近通知システム（利用者が事前に バス停と時刻を指定し、指定された時刻付近でその バス停に到着する到着予測を事前にメールや電話で 通知するシステム) と、(2)音声によるバス情報の提 供、であった。実験結果からは、リクエスト型バス 接近通知については、意識調査結果から肯定的意見 が多数（利用する $20 \%$ 、無料なら利用 $30 \%$ 、使用 性が上がれれば利用 $20 \%$ ）となり、本システムに おいて実用化した。音声案内についての同様に本シ ステムでの実用化を行った。

\section{(a) 到着予測の精度の問題}

実験時の手法としては、走行するバスに対して到 着する 5 分・10 分前のおおよその地点を事前調査 によって決定し、その地点を中心とした特定エリア にバスが到着するとリクエストデータと照合が行わ れ、自動的に情報提供が行われた。この場合、事前 に設定した地点そのものの精度の問題や、交通状況 の変化によって静的に決められている地点では、予 測が大きく異なってしまうといった問題が生じてい た。このため、本研究では実走行しているバスの位 置をデータベースとして利用し、過去の走行状況か ら動的に予測を行うシステムに変更した。

\section{(b) リクエスト予約方法の問題}

実験時には、バス利用者は実験本部に電話をか けて、オペレータとの会話を通して到着予測のリク エストを行った。これはフレキシブルな対応ができ るという利点はあったが、時間がかかることやオぺ レータの費用等、実用化にむけては大きな問題があ った。本研究では、リクエスト方法の完全自動化を 行い、WEB および音声 (CTI : Computer Telephony Integration）によるシステムに変更した。

\section{(3) 実用化へ向けての課題}

(a) 位置取得の方法

バス位置の取得方法に関しては、普及が進む GPS による手法を採用した。川越地区は高層ビル が少なく GPS 衛星を補足できない地点がほとんど 無いこと、2002 年 5 月 1 日からの GPS 信号におけ る意図的な誤差（SA：Selective Availability）の解除 による位置情報精度の向上等、大きな課題はない。

\section{(b) 費用}

バスロケーションシステムにおける費用の問題は 大きい。システム開発や設備導入等の莫大なイニシ ヤルコストは、補助金を適切に活用することでバス 事業者としての負担は軽減も可能である。一方、毎 日のランニングコストについても十分な検討が必要 である。本研究では、普及型 GPS 機器の活用によ る初期コストダウンと、パケット通信網を使うこと でバス位置情報の取得にかかる費用を安価に抑える ことにした。

\section{CO-EDO システムの開発}

\section{(1) CO-EDO システムの概要}

以上の様に、移動端末型のバス情報システムに 関する一般的課題、実験時に判明した課題、実用化 へむけての課題を整理した上で、平成 14 年 3 月か ら、実用化システムとして「CO-EDO システム」 の運用を開始した ${ }^{11)}$ 。対象路線は、イーグルバス 株式会社（本社：川越市）が運営する「小江戸巡回 バス」である。本路線は、川越駅を始発点とし、中 院、喜多院、蔵の街、菓子屋横丁などの川越の各観 光名所を巡回し川越駅へ戻る、路線長約 $10 \mathrm{~km}$ 、運 行時間約 50 分の路線（1 日 14 便、ミニバス）であ る。路線の特徴としては、巡回ルートが一方向だけ であり、乗客の大部分がそのルートに従って観光を 行う観光客であることがあげられる。なお、平成 14 年 1 月から 3 ヶ月間を試用期間とし、利用者モ ニターを募った上で使用性の向上を図った。

(2) CO-EDO システムの機能

(a) バス利用者のための機能

リアルタイムバス情報提供サービス

PC $の$ WEB、WEB 機能付携帯電話、自動音声応 答の三種類をインターフェイスとし、バスの現在情 
報をリアルタイムに配信する。利用者は、任意のイ ンターフェイスで情報を得ることができる（表 2）。

\section{表 2 リアルタイムバス情報提供の種類}

\begin{tabular}{|c|c|}
\hline $\begin{array}{l}\text { (1)バス現在 } \\
\text { 位置情報・ } \\
\text { 現在遅れ情 } \\
\text { 報 }\end{array}$ & $\begin{array}{l}\text { 現在位置情報は、PC 等の WEB では簡易地図 } \\
\text { 上に表示、携帯電話 WEB では簡易バス停表 } \\
\text { 示、音声電話では音声によりどのバス停間に } \\
\text { いるかといった情報が音声で提供。同時に、 } \\
\text { 現時点でバスが定刻よりどれだけ遅れている } \\
\text { かという情報が、「遅れO○分」と表示。 }\end{array}$ \\
\hline (2) & 過去のバス運行データより、バス停への予測 \\
\hline $\begin{array}{l}\text { 到着時刻情 } \\
\text { 報 }\end{array}$ & $\begin{array}{l}\text { 到着時刻を算出し提供。PC 等の WEB では全 } \\
\text { バス停で次到着バスの予測時刻を表示。携帯 } \\
\text { 端末 WEB では各バス停について、次に到着 } \\
\text { するバスの予測到着時刻を表示することに加 } \\
\text { え、各バスについて今後の運行予測を表示。 }\end{array}$ \\
\hline $\begin{array}{l}\text { (3)バス車内 } \\
\text { の混雑情報 }\end{array}$ & $\begin{array}{l}\text { バス車内の混雑状況は、「空席あり・立ち席 } \\
\text { あり・混雑」の } 3 \text { 段階に分けて表示。この情 } \\
\text { 報は、高齢者等座席を必要としている人々に } \\
\text { とっては有効な情報であると思われ、また混 } \\
\text { 雑の情報を得た利用者が次のバスへ転換する } \\
\text { ことによる利用客分散の効果も期待。なお、 } \\
\text { 混雑データは、連転手が車内混雑を目視で確 } \\
\text { 認して伝送装置に入力することで取得する。 }\end{array}$ \\
\hline (4)付加情報 & $\begin{array}{l}\text { 標準時刻表やバス停付近の観光情報・バス停 } \\
\text { 付近の地図といった利用者にとって有益と思 } \\
\text { われる情報も提供。 }\end{array}$ \\
\hline
\end{tabular}

リクエスト型接近通知サービス

このサービスは、利用者が乗車するバス停に対 し、希望した時刻に最も近い時刻に到着するバスの 接近時に、音声電話または電子メールにて接近情報 を通知するものである。接近通知の申し込み(リク エスト)方法は、PC の WEB、携帯端末 WEB、電話 （プッシュ音）を利用した自動音声応答システム 3 種類がある（図 1に携帯 WEB の例を挙げる）。
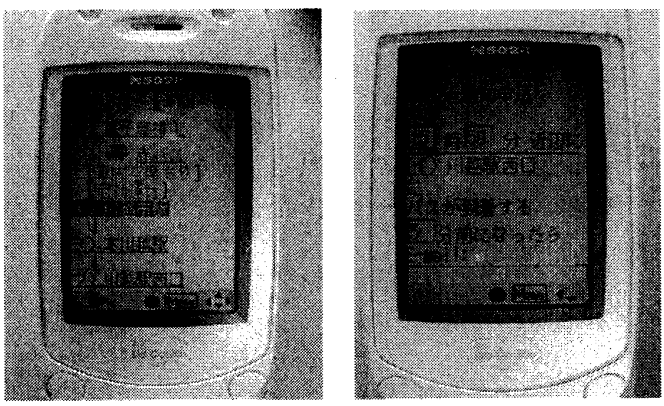

図 1 携帯端末の画面例

（右:バス現在情報、左:リクエスト入力画面）

PC・携帯端末 WEB のリクエストでは「電子メー ルによる通知」のみリクエストできる。電子メール は詐称によるいたずらが容易なため「WEB フォー

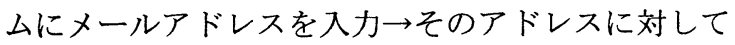

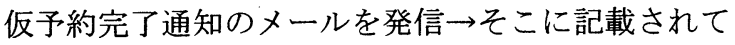
いる URL のリンクをクリック」することで予約が
完了する手順としてアドレス詐称を防止した。同様 に、音声電話によるリクエストは、リクエストの際 の発信者番号通知を必須とし、CTI システムで発信 者番号が取得できた場合のみ接近通知の発信を行う こととした。

\section{(b) バス管理者のための機能}

バス管理者のための機能としては、(1)全バスの 現在位置確認、(2)運行記録データの保管が挙げられ る。(1)では、バス運行本部においてバスがどの位置 にいるかをリアルタイムに地図上で確認することが でき、さらに車内の混雑状況もわかるため、従来の 無線によるシステムと併用することでスムーズな臨 時バス（混雑時の増便）の運行決定等より効率的な バス運用が可能となる。(2)では、全バス停の到着時 刻、区間の混雑状況の全てが記録されており、運行 見直し等におけるバス事業者の貴重なデータとなる。

\section{4. 到着予測の検討}

\section{(1) 到着予測の概要と要因}

到着予測の処理については、具体的には以下の 二種類の予測を実施している。

(1)バス接近通知に用いる「バス停到着 5 分前位置・

10 分前位置」の予測

(2)リアルタイムバス情報に用いる、各バス停におけ る「次バス到着時刻」の予測

到着時刻予測を行うにあたっては、天候等様々 な原因を考慮して予測を行うべきであるが、全てを 考慮するのは困難で計算量も多い。まず、天候等、 自動的にデータ取得が難しいものは予測に用いる要 素から外した。また、実運用期間が短いこともあり

「季節」は要素としない。以上のような事を考慮し た上で、到着時刻予測に用いる要素を以下のよう に設定した。

\section{(a) 過去のバス停間運行時間}

小江戸巡回バスは、約 30 分に 1 本運行されてい る。そこで、「バス停間運行時間」は、30 分前に 同路線を通過した前便のバスと類似したものになる であろうという仮定のもと、これを予測の要素とし た。「バス停間運行時間」はバス停到着から、次バ ス停に到着するまでの時間である。よって、この 「バス停間運行時間」では、バスがバス停に停止し 
ていた時間、例えば乗客の乗降時間等、とバスが走 行していた時間、例えば渋滞遅延等、がどちらも考 慮された要素であり、解釈としてはバス路線の道路 状況、乗客数、乗客の属性等の影響を考慮した数值 であると言える。

\section{(b) 曜日の区分}

本路線は市内の観光地を巡回するため、土休日 は乗客も多くなり乗降時間による遅れが生じること が多い。また、川越という土地自体が観光地である ため、土休日は道路混雑も発生しバスの遅れを生じ させている。よって、平日と土休日では「バス停間 運行時間」も異なるとして予測の要素とした。

\section{（2）実稼動システムにおける予測}

公共交通における到着時刻予測に関する研究は ほとんどされていない中 ${ }^{12) \sim 15) 、 C O-E D O ~ シ ス テ ム ~}$ では幹線道路等の所要時間予測として用いられてい る方式を用いることとした。それは、直前に走行し た（前便）バスの「バス停間運行時間」をそのまま 「予測バス停間運行時間」とする簡易的な手法であ る。このようなシステムで平成 14 年 3 月から本格 始動した。また始発便は、曜日を考慮した上で過去 の始発便のデータを検索して利用することとした。

\section{(a) 現在の予測精度}

2002 年 4 月から 5 月までの予測状況の結果を

表 3 に示す。また、代表的なバス停区間につい ての予測結果を図 2に示す。予測精度については概 してあまり精度が高いとは言い難く、5 分以上の誤 差が発生するケースもある。

\section{（3）予測精度を悪化させている要因}

精度を悪化させている要因はいくつか考えられ る。例えば GPS データ自体の誤差、GPS データの 取得エラー、極めて簡易的な予測手法を利用してい るなどがある。その中でも大きな誤差を生じさせ、 精度を悪化させていると考えられる主な要因を2つ 挙げる。

\section{(a) GPS データからバス停到着時刻への変換誤差}

1 点目としては、現在の CO-EDO システムでは、 バスの位置確認やバス停への到着時刻算出のために、 GPS データを 1 分間隔で取得（ポーリング）して いる。その結果、バス停上でちょうど GPS データ が取得されたとき以外のバス停の到着時刻は、GPS データの取得されたポイントと約 1 分後に取得され
表 3 現在の予測精度

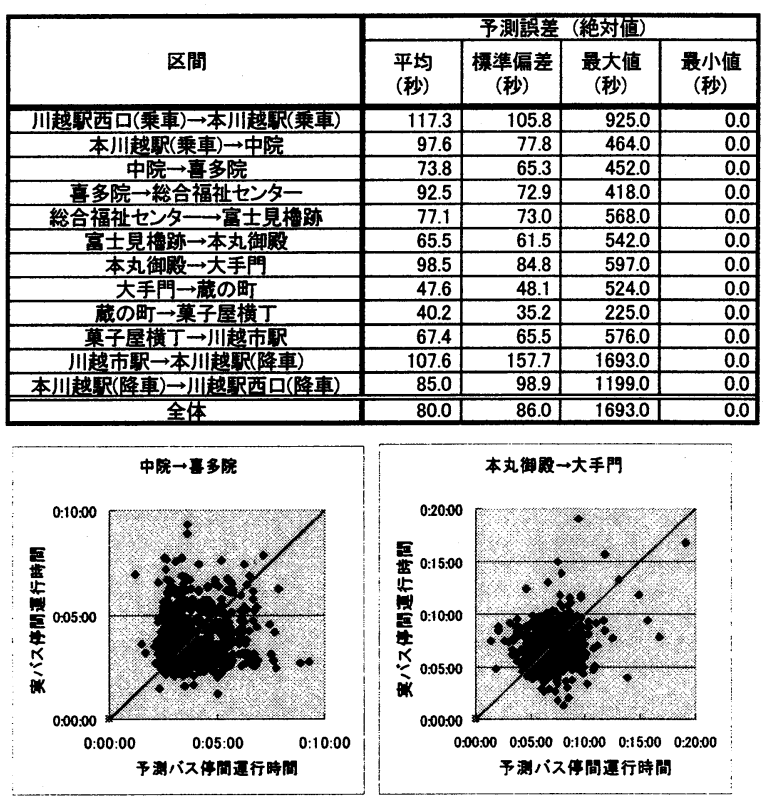

図 2 バス停間運行時間の予測值と実測值

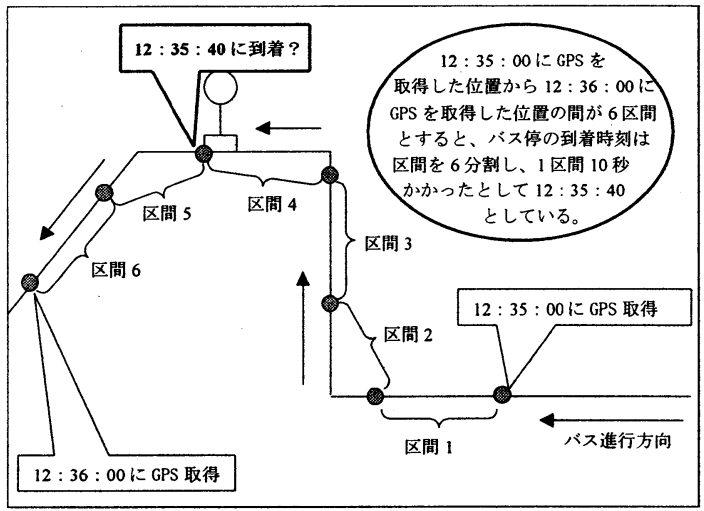

图 3 到着時刻算出方法

たポイントを単純に等分割して求める（図 3）。ポ イント間は等距離ではなく、信号で停止した場合や 渋滞が生じた場合を考えると単純に等分割した到着 時刻では誤差が発生する可能性が高い。

\section{(b)「走行時間」と「停車時間」の考慮}

2 点目としては、予測に用いている「バス停間運 行時間」が、バス停に到着した時刻から次のバス停 に到着するまでとなっている設定が挙げられる。こ の「バス停間運行時間」には「バス停における停車 時間」と「バス停間走行時間」の 2 種の内容を含ん でおり、それぞれ別々の要素の影響を受けている （表 4）。特に本路線では、平日に予定運行時刻よ り早めに到着して時間調整のために停止することが 多いことからも、精度向上を図るためには、これら 
をまとめて考慮することは適切ではなく、別のもの

として考慮する必要がある。

表 4 バス停間運行時間の区分

\begin{tabular}{|l|l|l|}
\hline \multicolumn{1}{|c|}{ 分類 } & \multicolumn{1}{|c|}{ 内容 } & 大きな影響要素 \\
\hline $\begin{array}{l}\text { バス停 } \\
\text { 停車時間 }\end{array}$ & $\begin{array}{l}\text { 乗客の乗降時間 } \\
\text { 定刻より早く着いた場合 } \\
\text { の時間調整 等 }\end{array}$ & 乗降客数 \\
\hline $\begin{array}{l}\text { バス停間 } \\
\text { 走行時間 }\end{array}$ & $\begin{array}{l}\text { 通常の走行時間 } \\
\text { 渋帯による遅れ時間 } \\
\text { 信号による停止時間 等 }\end{array}$ & バス路線の道路 \\
\hline
\end{tabular}

\section{(4) 問題点の検証 - 分析}

この 2 つの問題点を検証・分析するに当たって は（a）の指摘にあるように、現在までに蓄積され ているデータを活用することはできない。このため、 平成 15 年 1 月に実測調査を行った（表 5）。

\section{表 5 実測調査概要}

\begin{tabular}{|c|c|}
\hline 調査日 & 2003 年 1 月 18 日〜 1 月 26 日 \\
\hline 調査対象 & 1 日当り 1 便〜14 便、期間中全てで 126 便 \\
\hline 調查方法 & 調査員がバスに乗車し、紙面に記録する \\
\hline 記録内容 & $\begin{array}{c}\text { バス停の到着時刻・出発時刻・通過時刻 } \\
\text { バス停での乗降客数 }\end{array}$ \\
\hline
\end{tabular}

\section{(a) 変換誤差の検証}

実測データと GPS データによる前バス停出発時 の次バス停の到着予測時刻の比較結果を表 6 に示 す。 1 分間隔の GPS データ取得では、最大 407 秒 (大手門)、全区間の平均で約 35 秒の誤差が生じる ことから、GPS 取得間隔の再検討が必要である。

表 6 実測データと変換データの誤差

\begin{tabular}{|c|c|c|c|}
\hline & データ数 & 最大誤差(秒) & 平均誤差(秒) \\
\hline 1)川越駅西口(乗) & 86 & 159 & 28.3 \\
\hline 2)本川越駅(乗) & 84 & 77 & 17.8 \\
\hline 3)中院 & 84 & 130 & 52.9 \\
\hline 4)喜多院 & 85 & 64 & 17.8 \\
\hline 5)総合福祉センター & 84 & 266 & 69.6 \\
\hline 6)富士見櫓跡 & 84 & 78 & 23.3 \\
\hline 7)本丸御殿 & 85 & 168 & 57.9 \\
\hline 8)大手門 & 78 & 407 & 55.2 \\
\hline 9)蔵の街 & 78 & 200 & 26.5 \\
\hline 10)菓子屋横 T & 80 & 61 & 16.9 \\
\hline 11)川越市駅 & 82 & 135 & 15.3 \\
\hline 12)本川越駅(降) & 81 & 84 & 15.7 \\
\hline 13)川越駅西口(降) & 83 & 366 & 50.9 \\
\hline 平均 & & & 34.5 \\
\hline
\end{tabular}

\section{(b)「走行時間」の分析}

走行時間の分析結果を表 7、図 4に示す。走行 時間は、次の 2 種類に大別される（表中の網掛がそ の代表例)。1 つ目は標準偏差の小さい区間（図 4 左）で、非幹線道路を走行するため交通混雑が起こ りにくく、走行時間が比較的安定している区間であ る。2つ目は標準偏差の大きい区間（図 4右）で、
幹線道路を走行し、渋滞や信号待ち等が発生しやす く走行時間にばらつきが生じてしまう区間である。

\section{表 7 走行時間分析}
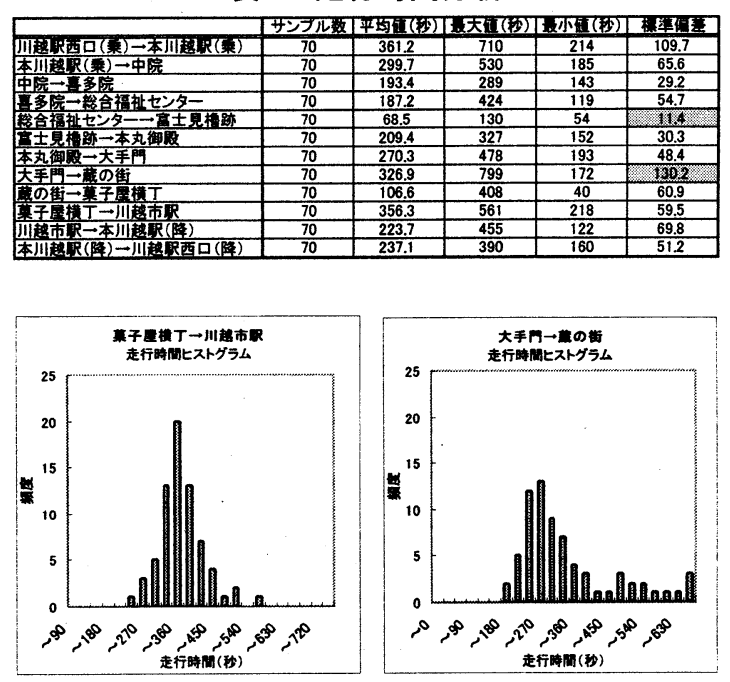

図 4 走行時間のヒストグラム

\section{(c)「停車時間」の分析}

停車時間とは、利用者の乗降時間と時刻調整の ための待合せ時間とに区分できる。この停車時間は 以下の 2 パターン存在する（図 5）。

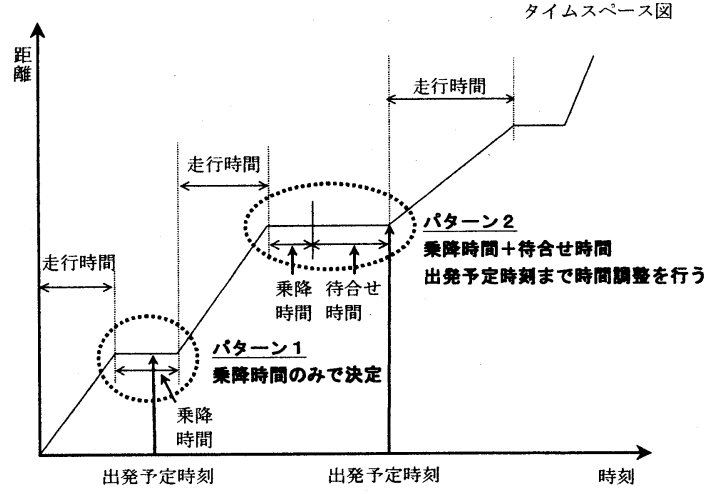

パターン1:

出発予定時刻を越えて乗降がなされる パターン 2:

出発予定時刻より早く乗降が終了し待合せが 発生する

\section{図 5 乗降時間と待合せ時間と出発予定時刻の関係}

\section{(i )乗降時間·乗降人数分析}

小江戸巡回バスは一般の路線バスと異なり、乗降 ロが同じである。よって、乗降にかかった時間を目 的変数 $(\mathrm{y})$ 、乗車人数を第 1 説明変数 $(x 1)$ 、降車 
人数を第 2 説明変数 $(x 2)$ とし、サンプル数 581 で 重回帰分析を行った。その結果、 $\mathrm{y}=1.93 \mathrm{x} 1+$ $5.40 \times 2+15.7$ という線形の重回帰式（重相関係数 0.63、重決定係数 0.40）が求まった。これより、乗 降人数が求まれば、ある程度乗降時間が予測できる ことがわかった。次に、乗降人数の予測方法を見出 すためバス停ごとの乗車人数・降車人数を調査した (平日のみ)。その結果の一例を図 6、図 7に示す が、「喜多院」は観光ルート前半にあるため、午前 中に降車し昼頃に乗車するといった傾向が見られた。 しかし、具体的に何人乗降するかの予測手法の提案 は現段階では困難であると判断した。

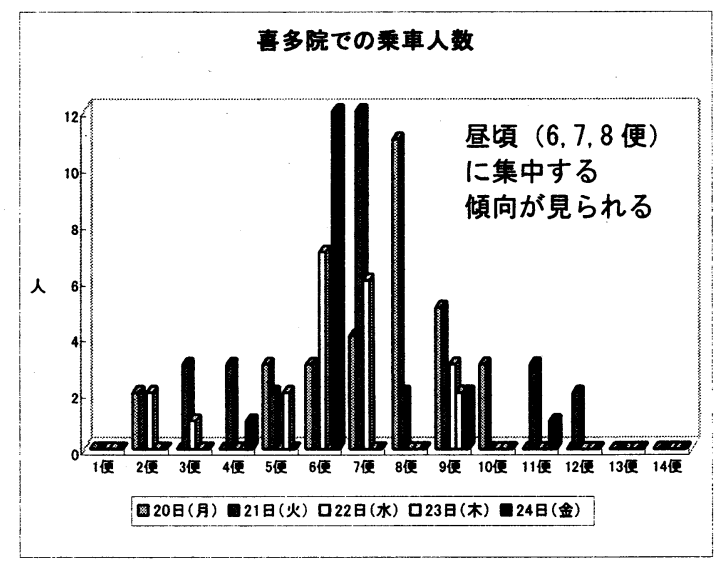

図 6 時間帯ごとの乗車人数

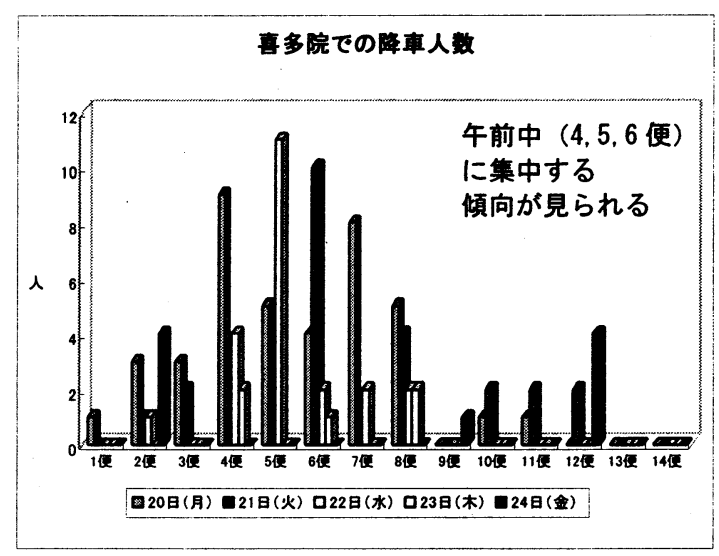

図 7 時間帯ごとの降車人数

(ii) 時刻調整のための待合せ時間の検証

小江戸巡回バスは、平日では時刻表の運行予定 より早い時刻に到着し、時間調整のために停止する ことが多い。現在の到着予測手法において、この待 合せ時間が予測に誤差を生じさせていた大きな要因 であると考えられる。よって、本当に時刻調整のた
めの待合せ時間が影響を与えているのか検証した。 調査結果から、待合せはきちんと行われ、最大で 304 秒待合せを行っていることが明らかになった

（表 8）。以上より待合せ時間を考慮することは必 要であるといえる。

\section{表 8 待合せ回数と最大待合せ時間}

\begin{tabular}{|c|c|c|c|c|c|c|c|}
\hline \multirow[b]{2}{*}{ バス停名 } & \multicolumn{6}{|c|}{ 2003年1月18日 (土) 〜1月26日（日） } & \multirow[b]{2}{*}{$\begin{array}{c}\text { 最大 } \\
\text { 待合せ } \\
\text { 時間(秒) }\end{array}$} \\
\hline & $\begin{array}{c}\text { （天停 } \\
\text { 到着数 }\end{array}$ & $\begin{array}{l}\text { 待合せ } \\
\text { するべき } \\
\text { 状況に } \\
\text { なった } \\
\text { 回数 }\end{array}$ & $\begin{array}{c}\text { 通過のため } \\
\text { 待合せ } \\
\text { しなかかた } \\
\text { 回数 }\end{array}$ & $\begin{array}{l}\text { バス停に } \\
\text { 停車しが } \\
\text { 待合せ } \\
\text { しなかった } \\
\text { 回数 }\end{array}$ & $\begin{array}{c}\text { 時刻暗整 } \\
\text { した回数 } \\
\text { (1分以上 } \\
\text { 早<出発). }\end{array}$ & $\begin{array}{l}\text { 時刻咋整 } \\
\text { Lた回数 } \\
\text { (土1分以内 } \\
\text { (出発) }\end{array}$ & \\
\hline 2)本川越駅(乗) & 125 & 47 & 1 & 0 & 0 & 46 & 155 \\
\hline 3)中院 & 125 & 63 & 2 & 0 & 1 & 60 & 173 \\
\hline 4)喜多院 & 125 & 10 & 4 & 0 & 0 & 6 & 110 \\
\hline 5)総合福祉センター & 125 & 99 & 0 & 0 & 0 & 99 & 304 \\
\hline 6)富士見態跡 & 125 & 6 & 6 & 0 & 0 & 0 & 15 \\
\hline 7)本丸御即 & 125 & 81 & 1 & 1 & 0 & 79 & 158 \\
\hline 8)大手門 & 125 & 16 & 11 & 1 & 0 & 4 & 45 \\
\hline 9)蔵の街 & 125 & 0 & 0 & 0 & 0 & 0 & 0 \\
\hline 10)菓子屋横丁 & 125 & 6 & 1 & 0 & 0 & 5 & 56 \\
\hline 11)川越市駅 & 125 & 7 & 0 & 1 & 0 & 6 & 77 \\
\hline 12)本儿越䭾(降) & 125 & 1 & 0 & 0 & 0 & 1 & 30 \\
\hline
\end{tabular}

（5）新たな予測手法の提案

分析結果から新しい予測手法の提案を行う。

【走行時間】

今回の分析からは、単純な前便参考・前週同便参 考などからは関係性が見られなかったため、現在 と同様の前便参考を基本とする。

【停車時間】

パターン1:

回帰式を用いて乗降時間を算出し、それを停車時 間とする。降車時には料金支払い作業があるため に係数が大きくなった。また、具体的な人数予測 の提案は困難であったため、乗車人数・降車人数 の予測值は、同時間帯の平均を用いることとする。 $\mathrm{y}=1.93 \times 1+5.40 \times 2+15.7$

$\mathrm{y}$ : 乗降時間 $\mathrm{x} 1$ : 降車人数 $\mathrm{x} 2$ : 乗車人数 パターン 2:

出発予定時刻まで時間調整を行う。

(a) 新たな予測手法による区間ごとの予測精度

現在の予測手法と提案した新たな予測手法の予 測誤差を比較した。区間ごとの実時間と予測時間の 一例を示す。待合せが行なわれていた区間や走行時 間が比較的安定している区間の予測精度は RMS 誤 差から見ても改善されたといえる（図 8）。一方、 走行時間にばらつきがある区間はほとんど改善が見 られない（図 9）。 


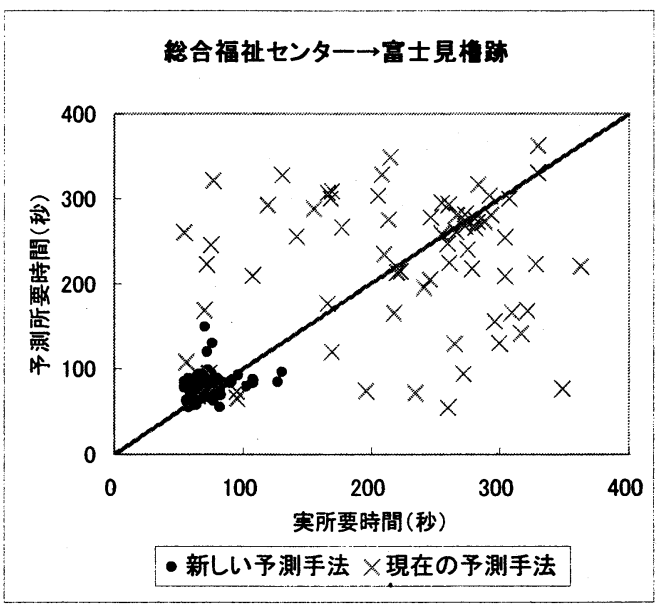

RMS譟差(秒)

新たな手法 : 19.9 現在の手法 : 106.5

图 8 現在の手法と新たな手法の誤差比較

（改善された区間）

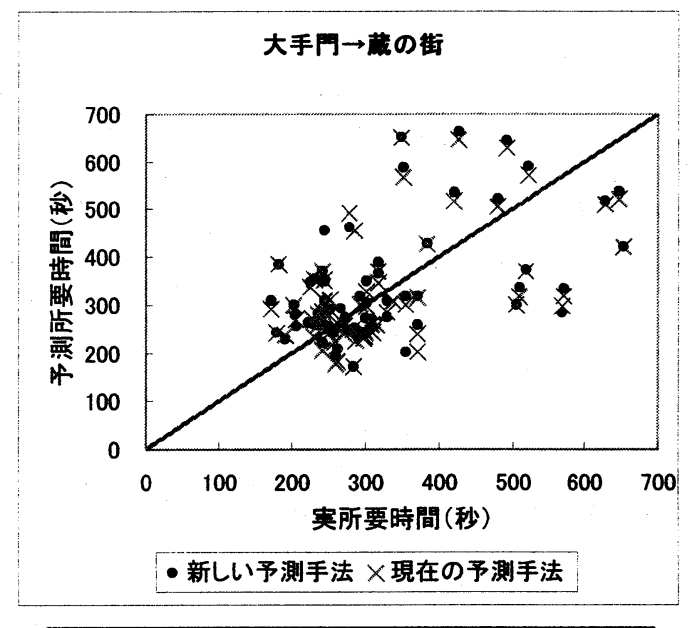

RMS誤差(秒)

新たな手法：126.5 現在の手法 ：126.4

図 9 現在の手法と新たな手法の誤差比較 （改善されなかった区間）

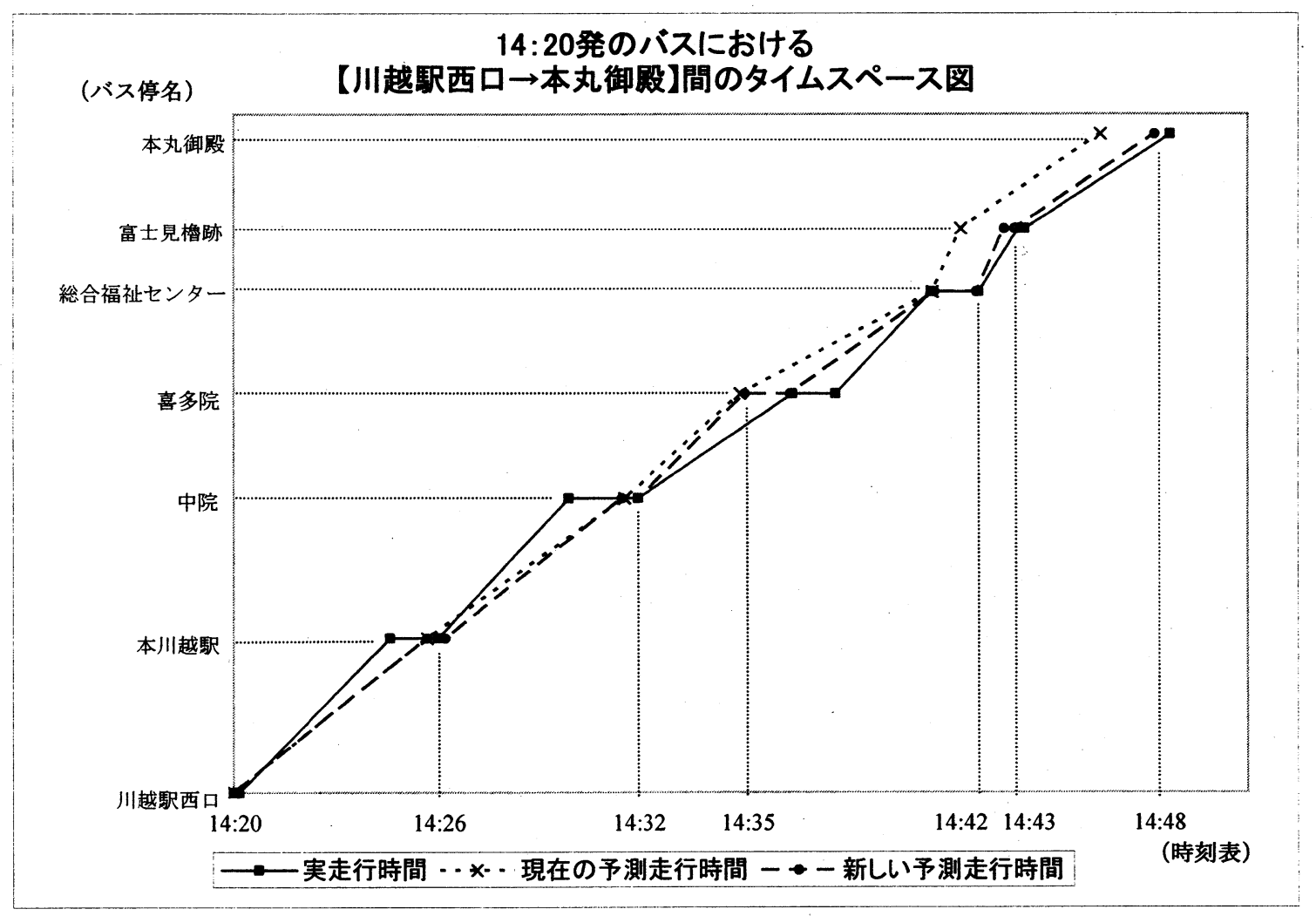

図10 タイムスペース図

（b）新たな予測手法による 1 便を通しての予測精度 区間単位ではなく 1 便通して全区間の予測精度 向上を確認するために、タイムスペース図を用いて 検討を行った。図 10にその一例を示す。その結果、
現在の予測手法と比べて新たな予測手法がより実測 值に近づいていることが確認できた。 


\section{5. おわりに}

本研究では、バス交通を支援する有効なツールで あるバス情報提供システムについて、社会実験の結 果を踏まえ、使用性、信頼性、安定性等を持ち合わ せた実用化システムとして開発した。また、現在の 予測手法の問題点を改善し精度向上の方向性を見出 だした。

今後は、今回は十分に分析できなかった平日と休 日の差や季節変動について、蓄積されている多量の 運行データの解析を試みることでモデル構築を行う ことや、交通量データとのリンクによって走行時間 を混雑度などの新たなパラメータを用いて予測する 手法の検討など、さらに精度の高い到着時刻予測の 手法を生み出すことが課題である。また、乗降セン サーやICカードの導入によりバス停毎の乗客ODデ 一タを取得することにも大きな期待がある。さらに、 提供する予測時刻の精度について、利用者はどこま で許容できるのかといった課題についても整理が必 要であり、管理者を含めたシステム利用者にとって も使いやすく便利なシステムにすることも大きな課 題である。

\section{参考文献}

1)中澤良規、坂本邦宏、久保田尚：リクエスト・自動コール 型バス情報提供システムに関する実験的研究、第 21 回交 通工学研究発表会論文集, pp.105-108，2001.10

${ }^{2)}$ http://www.city.kyoto.jp/kotsu/news/bls/bls_manu_top.htm/ (携 帯端末)

${ }^{3)} \mathrm{http} / / /$ www.okakoku-mlit.go.jp/dat_frame/fr_02_04.html/ (PC)

4) http://www2.okakoku-mlit.go.jp/bus/ (携帯端末)

${ }^{5)} \mathrm{http}: / /$ navi.entetsu.co.jp/ (PC)

${ }^{6)} \mathrm{http}: / /$ navi.entetsu.co.jp/i/ (携帯端末)

${ }^{7)} \mathrm{http}: / / \mathrm{www}$.sendai-mlit.go.jp/cgi-bin/bus/location.cgi/ (PC)

${ }^{8)}$ http://www.thr.mlit.go.jp/sendai/i.html/ (携帯端末)

${ }^{9)}$ http://www.kanazawa.go.jp/bus/ (PC および携帯端末共通)

${ }^{10)} \mathrm{http} / / /$ tobus.jp/ (PC および携帯端末共通)

${ }^{11)} \mathrm{http} / / / \mathrm{www} . c 0-$ edo.com/ (PC および携帯端末共通) (以上 ${ }^{3)}$ ～$^{11)}$ の web サイトは 2003/03/01 現在のもの)

12) 山根憲一郎、横田孝義、伏木匠 : 高精度化をめざした旅 行時間推定法に関する研究、第 21 回土木計画学研究・講 演集, pp.897-900, 1998.11

13）割田博、吉田寛：首都高速道路における所用時間変動特 性の分析、第 22 回交通工学研究発表会論文集, pp.61-64, 2002.10

14）上野秀樹、大場義和、桑原雅夫 : 所要時間履歴情報を用 いた走行時間予測モデルの研究、第 22 回交通工学研究発 表会論文集，pp.169-172，2002.10

15) 斎藤純一、割田博、田中淳 : 事故・工事時における所用 時間予測手法に関する研究、第 22 回交通工学研究発表会 論文集，pp.173-176，2002.10

\section{利用者ニーズに対応した到着時刻予測に基づくバス情報システムの害用的開発}

坂本邦宏、久保田尚、中村要、菅野光司、谷島賢

バス交通が衰退の状況を辿っている中で、それを改善すべく多様なニーズに対応する施策などが 行なわれてきている。特に、「バス情報提供システム」は全国各地で実験や実用化がなされており 成果を上げている。このような背景のもと、既存のバスロケーションシステムからその長所・短所 等を検討することにより、実用システムとしての使用性・信頼性・安定性を持ち合わせた「バス情 報提供システム」を構筑することを目的とした。また、構筑したシステムの主要機能である「バス 到着時刻予測」の予測精度向上のための手法を見出すことも試みた。

\section{Practical development of a bus information system based on the time-of-arrival prediction corresponding to user needs}

Kunihiro SAKAMOTO, Hisashi KUBOTA, Kaname NAKAMURA, Koji KANNO, Ken YAJIMA

While bus traffic is following the situation of a decline, many policies corresponding to various needs has been performed in order to improve it. Especially the bus information system is achieving success. The basis of such a background, merit and demerit are examined from the existing bus location system and as a practical system, the bus information system which had usability, reliability, and stability with it was built. Moreover, it tried to find out the technique for the improvement in accuracy of "bus time-of-arrival prediction" which is the main function of the built system. 